\title{
Correlation between in-brace radiographic correction and short time brace results
}

\author{
F Zaina ${ }^{1 *}$, S Donzelli ${ }^{1}$, M Lusini ${ }^{2}$, S Negrini ${ }^{1}$ \\ From 8th International Conference on Conservative Management of Spinal Deformities and SOSORT 2011 \\ Annual Meeting \\ Barcelona, Spain. 19-21 May 2011
}

\section{Background and purpose}

In-brace X-ray is considered a reliable check of brace efficacy [1-3]. The aim of this study was to correlate the in-brace correction with the short term results of treatment (6 months).

\section{Materials and methods}

Design: pre-post study.

Population: 41 consecutive adolescent girls with idiopathic scoliosis who were prescribed a brace treatment (39 thoracic curves, $37 \pm 12^{\circ}$; 16 thoracolumbar, $38 \pm 13^{\circ}$; 12 lumbar, $31 \pm 8^{\circ}$. Risser $0-3$ ).

In-brace X-ray and 6 months treatment out of brace $\mathrm{X}$-ray results were correlated, according to curve localization. The in-brace/out-of-brace ratio was calcutated, curves were grouped according to the Risser sign, the results $\left(<10^{\circ},{ }^{3} 10^{\circ}\right.$ out-of-brace), in-brace correction $\left(<10^{\circ},{ }^{3} 10^{\circ}\right)$, the magnitude $\left(<30^{\circ}, 30^{\circ}-45^{\circ},>45^{\circ}\right)$.

Statistical analysis: Correlation Coefficient.

\section{Results}

The in-brace/out-of-brace ratio varied according to localization of curve and Risser, achieving the best results for Thoracic curves (38-45\%). The groups of Thoracolumbar and Lumbar had higher variability (17-65\% and $17-40 \%)$. The correlation coefficient between in-brace correction and out of brace results was statistically significant: 0.85 for Thoracic curves, 0.64 thoracolumbar, 0.72 lumbar. Risser groups: 0.65-0.98 Thoracic, 0,78-0.90 Thoracolumbar, 0.94-0.98 Lumbar. For Results groups, the correlation was better for High results in lumbar and Low results for thoracolumbar, no differences for thoracic. Low in-brace correction had a low correlation coefficient for thoracic and lumbar curves. No differences for Magnitude.

${ }^{1}$ ISICO Milan, Italy

Full list of author information is available at the end of the article

\section{Conclusions}

The correction after 6 months of brace are $17-47 \%$ of the in-brace correction. The correlation between inbrace correction and short time results of brace is significant, range 0.64-0.98. The in-brace correction seems able to predict the short time results of treatment.

\section{Author details}

${ }^{1}$ ISICO Milan, Italy. ${ }^{2}$ Siena University, Italy.

Published: 27 January 2012

References

1. Clin J, Aubin CE, Sangole A, Labelle H, Parent S: Correlation between immediate in-brace correction and biomechanical effectiveness of brace treatment in adolescent idiopathic scoliosis. Spine 2010, 35(18):1706-13.

2. Weiss HR, Rigo M: Expert-driven Chêneau applications: description and in-brace corrections. Physiother Therory Pract 2011, 27(1):61-67.

3. Landauer $\mathrm{F}$, Wimmer $\mathrm{C}$, Behensky $\mathrm{H}$ : Estimating the final outcome of brace treatment for idiopathic thoracic scoliosis at 6-month follow-up. Pediatr Rehabil 2003, 6(3-4):201-7.

doi:10.1186/1748-7161-7-S1-O27

Cite this article as: Zaina et al:: Correlation between in-brace radiographic correction and short time brace results. Scoliosis 2012 7(Suppl 1):O27.

Submit your next manuscript to BioMed Central and take full advantage of:

- Convenient online submission

- Thorough peer review

- No space constraints or color figure charges

- Immediate publication on acceptance

- Inclusion in PubMed, CAS, Scopus and Google Scholar

- Research which is freely available for redistribution

Submit your manuscript at www.biomedcentral.com/submit
() Biomed Central

\section{() Biomed Central}

(c) 2012 Zaina et al; licensee BioMed Central Ltd. This is an open access article distributed under the terms of the Creative Commons Attribution License (http://creativecommons.org/licenses/by/2.0), which permits unrestricted use, distribution, and reproduction in any medium, provided the original work is properly cited. 